\title{
"Will You Not Teach ruqyat al-namla to This (Woman) ...?": Notes on a Hadith's Historical Uncertainties and Its Role in Translations of Muḥammad
}

\author{
Aisha Geissinger
}

In the course of his biographical entry for Hafșa bt. 'Umar b. al-Khațāāb (d. ca. 45 AH/665 CE), Ibn Sa'd (d. 23o/845) recounts a number of traditions. Many of these deal with her father 'Umar's efforts to find her a husband after she had become widowed, and aspects of her apparently rather tumultuous marriage to Muhammad. Among the hadīths that Ibn Sa'd relates is the following: “... The Messenger of God visited Hafșa, and with her was a woman-she was called al-Shifā-p - performing an incantation against namla. ${ }^{1}$ He said, 'Teach it to Hafșa.'"2 Another version of this hadith appears in the Musannaf 'Abd al-Razzāq (d. 211/826) with the following wording: “... The Prophet said to a woman, 'Will you not teach ruqyat al-namla ${ }^{3}$ to this (woman)'-he meant Hafșa, his wife- - just as you taught her writing?' "4

What does this tradition (henceforth, "the ruqyat al-namla tradition") "mean"? It can be fairly described as both reasonably well known today, yet at the same time quite obscure. This hadith has been quoted or alluded to fairly often in conservative Sunni Muslim discourses about women's roles since the nineteenth century CE until the present. When the point at issue in such discourses relates in some way to women's education, it is often employed as a proof-text testifying to Hafșa's literacy, and the Prophet's approval of that. ${ }^{5}$ In

1 On the meaning of namla, see below.

2 Muḥammad b. Sa‘d, Al-Ṭabaqāt al-kubrā, eds. Hamza al-Nashratī et al. (Cairo: al-Maktaba alQayyima, n.d.), 8:95.

3 I.e. an incantation against namla.

4 'Abd al-Razzāq b. Hammām al-Ṣan'ānī, Al-Muṣannaf, ed. Habīb al-Raḥmān al-A'ẓamī (Beirut: al-Maktab al-Islāmī, 1970-1972), 11:16 (Kitab al-Jāmic).

5 For the use of this tradition by the late nineteenth century Sunni scholar Shams al-Haqq al'Az̄ìmābādī in order to argue in favour of women being taught how to write, see Asma Sayeed, "Muslim Women's Religious Education in Early and Classical Islam," Religion Compass 5, no. 3 (2011): 96. For a recent reference to this tradition as part of a larger (theological rather than 
academic historical scholarship, this tradition is sometimes treated as evidence that al-Shifä' was literate. ${ }^{6}$ While this situation might give the impression that the import of this hadith is quite straightforward, one does not have to delve far into either its history of interpretation or its transmission history to discover that if anything, the opposite is the case.

For example, the word "ruqya" denotes an incantation for healing or protection that involves reciting words over people, with or without blowing one's breath on them, and sometimes also using certain materials, such as spit, water or dust. ${ }^{7}$ What type of healing or other benefit that the particular type of ruqya known as ruyqat al-namla is intended to produce was, however, a matter of some debate from at least the early third/ninth century on. Also, while some versions of this hadith mention writing, others do not, which raises questions about its "original" form, as well as why the presumably oral practice of ruqya would at times be associated with writing.

In what follows, we will examine the ruqyat al-namla tradition from two main angles: Employing some typical approaches to the study of hadiths, Part I discusses this tradition's cast of characters, as well as its provenance and early transmission as presented in its isnäds. The question of what it might—and most likely does not—indicate about literacy in Muhammad's community will also be briefly addressed. The results are rather inconclusive for several reasons, as we will see. Part II analyses the ruqyat al-namla tradition as an example of what I term the process of "imperial translations" of Muhammad. ${ }^{8}$ A vital

historical) argument that in pre-modern "mainstream" Sunni Islam, women's access to religious study — including their learning to write - and teaching of others were uncontroversial from the beginning, see Muhammad Akram Nadvi, Al-Muhaddithät: The Women Scholars in Islam (Oxford and London: Interface, 2007), 54.

6 E.g. "Al-Shifä' ... was literate .... This can be inferred from the Prophet's order to her, 'Teach Hafșa ...'” (Michael Lecker, "The Preservation of Muhammad's Letters," in People, Tribes and Society in Arabia Around the Time of Muhammad, ed. Michael Lecker (Aldershot: Ashgate Variorum, 2005), 6).

7 Abū Bakr 'Abdallāh b. Muḥammad b. Ibrāhīm b. Abī Shayba, Al-Mușannaf, eds. Ḥamad b. 'Abdallāh al-Jum'a and Muhammad b. Ibrāhīm al-Lahīiān (Riyadh: Maktabat al-Rushd, 2004), 8:33, 35-36 (Kitāb al-Ṭibb); Abū Dāwūd Sulaymān al-Ash'ath al-Sijistānī, Sunan Abì Dāwūd, ed. Șidqī Muḥammad Jamīl (Beirut: Dār al-Fikr, 1994), 3:395 (Kitāb al-Tiibb). For the use of this and related methods of healing in Saudi Arabia and the Gulf during the early twentieth century, see Eleanor Abdella Doumato, Getting God's Ear: Women, Islam, and Healing in Saudi Arabia and the Gulf (New York: Columbia University Press, 200o), 136-146.

8 My thinking about this process began when I learned of Peter Brown's work on the translation of Christian saints' relics-meaning the transfer of relics from the place(s) where a given saint lived and died to sacred sites in other locales, which then become places where believers can encounter the holy person; see his The Cult of the Saints: Its Rise and Function in Latin Christianity (Chicago: University of Chicago Press, 1981), 88-105. His analysis of this phe- 
and multifaceted function of hadiths down through the centuries has been to provide imperial translations of him (and to varying extents, also of his Companions and other leading early figures). By this I mean that while they recount sayings or anecdotes which are set in first/seventh century north-west Arabia, these are also represented and utilised in such a way that these words or lived examples can be made to seem to transcend the limitations of time and space. As such, they can address later generations of believers who live under very different political, economic, social and cultural conditions which are increasingly distant from the first/seventh century north-west Arabia. This process of translation was (and still is) ongoing, and its momentum depends on various factors that are open to historical analysis.

As we will see, the ruqyat al-namla tradition presents an anecdote set in Medina that depicts Muhammad providing a directive to an early Muslim female figure which can be and is made to address significantly different contexts and sets of circumstances: post-conquest Muslim imperial anxieties about identity, communal boundaries, and social as well as cosmic order. In this particular case, these anxieties are expressed through legal and theological debates during the second/eighth and third/ninth centuries and later regarding the acceptability of certain healing and protective practices. By the fourth/tenth century, they are also voiced in the use of this tradition as a prooftext in debates as to whether women should be taught how to write.

\section{Part I: Key Aspects of the Content and Transmission of the ruqyat al-namla Tradition}

\subsection{The Cast of Characters: Who Was al-Shifä̀?}

In the version of the ruqyat al-namla tradition found in 'Abd al-Razzāq's Muṣannaf, both the woman who is directed by Muhammad to teach the incantation against namla as well as the woman who is to be taught this appear to have been "originally" nameless. A transmitter's comment identifies the latter as Hafșa, one of the wives of the Prophet. The version given by Ibn Sa'd states (again, in what is seemingly a transmitter's interjection) that the former woman was called "al-Shifāa", though as his biographical dictionary has entries for two dif-

nomenon led me to ask questions about the ritual, social, and theological functions of Sunni compilations of hadiths from various regions in the Muslim empire from the second/eighth to the fourth/tenth centuries. For hadiths as a type of relic of the prophet Muhammad, see Brannon Wheeler, Mecca and Eden: Ritual, Relics, and Territory in Islam (Chicago and London: University of Chicago Press, 2006), 12, 75-78. 
ferent women with this name, this does not clearly identify her. ${ }^{9}$ However, the version provided in 'Abdallāh b. Wahb's (d. 197/812) Jāmi' renders it as "the Messenger of God said to al-Shifā' bt. 'Abd Allāh - and she was the grandmother of Abū Bakr b. Sulaymān b. Abī Ḥathma-'Why do you not teach this one-he meant Ḥafșa, his wife-ruqyat al-namla ...?" "10 Such transmitters' comments suggest a trend over time to render this tradition more concrete and thus memorable to audiences/readers, as well as to enhance its usefulness as a legal prooftext by giving names to its cast of characters.

While the prophet Muḥammad as well as his wife Ḥafșa require little introduction, ${ }^{11}$ the third figure, al-Shifā', is comparatively less well-known. Nonetheless, brief entries exist for al-Shifä̀ in some of the earliest biographical sources that have come down to us, as well as in a number of later medieval works. In the short biographical entry provided in Ibn Sa'd's Tabaqāt, her paternal and maternal lineages are given, indicating that she is from the same clan as Hafșa, as well as 'Umar b. al-Khațtāa. It is stated that her conversion took place well before the hijra, ${ }^{12}$ that she was among those women who pledged allegiance to the Prophet, and also, that she made the hijra to Medina. That she married Abū Ḥathma b. Ḥudhayfa and bore him a son, Sulaymān, is noted, along with her bearing another son, Abū Ḥakīm, in a different relationship..$^{13}$ In his even briefer entry for al-Shifäà, Ibn Khayyāt (d. 240/854) only gives her name, and information about her lineage which diverges somewhat from that provided by Ibn Sad, but presents the same general impression of her ancestry and clan membership. ${ }^{14}$

Over time, this rather shadowy female figure seemingly acquires more solidity with respect to two aspects of her biography: (1) information that would be of particular interest to hadīth critics, and (2) details about her status within Muhammad's community following her migration to Medina. With regard to the first type of material, Ibn Hibbān (d. 354/965) asserts that her name was in fact Laylä ${ }^{15}$ (though some later biographical works seem doubtful about

9 I.e. al-Shifā’ bt. 'Awf (Ibn Sa’d, Ṭabaqāt, 8:287), as well as al-Shifä' bt. 'Abdallāh (Ibn Sa'd, Tabaqāt, 8:310).

10 'Abdallāh b. Wahb b. Muslim al-Qurashī, Al-Jāmi' fì l-ḥadīth, ed. Mușțafā Ḥasan Muḥammad Abū al-Khayr (Dammam: Dār Ibn al-Jawzī, 1996), 2:789-79o (Fì al-ruqya).

11 For Ḥafșa, see for example Ibn Sa'd, Tabaqāt, 8:91-97.

12 "aslamat al-Shifäà qabla l-hijra qadìman."

13 This was with Abū Ḥathma’s brother, Marzūq b. Ḥudhayfa (Ibn Sacd, Ṭabaqāt, 8:310).

14 Khalīfa b. Khayyāt, Kitāb al-țabaqāt, ed. Suhayl Zakkār (Damascus: Ministry of Culture, 1966), 2:868.

15 Abū Ḥātim Muhammad b. Ḥibbān, Kitāb al-thiqāt, eds. Ibrāhīm Shams al-Dīn and Turkī Farḥān al-Muṣṭafā (Beirut: Dār al-Kutub al-'Ilmiyya, 1998), 1:43o. 
this), ${ }^{16}$ and Ibn 'Abd al-Barr (d. 463/1070) says that al-Shifä' (lit. "cure") was actually her nickname. ${ }^{17}$ None of the sources consulted for this study elect to pass on Ibn Sa'd's statement that she bore a son to Marzūq. That al-Shifä' had a married daughter can be inferred from a hadīth quoted by al-Ḥākim al-Naysābūrī (d. 405/1014) in his entry for her in his Mustadrak, as well as by Izz al-Dīn Ibn alAthīr (d. 63o/1234) in his Usd al-ghāba, and Ibn Ḥajar al-'Asqalānī (d. 852/1449) in his $I s ̦ \bar{a} b a,{ }^{18}$ but none of these entries note this explicitly. It seems that this relative lack of interest in such details stems at least in part from the fact that neither Abū Hakīm (the son she reportedly had with Marzūq) nor her daughter appear to have been remembered as having related any hadiths from her. However, nearly all compilers note that Sulaymān b. Abī Hathma was her son, and from al-Ḥākim al-Naysābūrī onward two of her grandsons, Abū Bakr and 'Uthmān, both sons of Sulaymān from different mothers, ${ }^{19}$ are mentioned. AlMizzī (d. 742/1341) and Ibn Ḥajar also state that al-Shifä' had a mawlä, ${ }^{20}$ Abū Ishāāq. ${ }^{21}$ These men are all credited with having transmitted hadiths on her authority.

While Ibn Sa'd says nothing in his entry for al-Shifä' about her life posthijra, biographers from the fifth/eleventh century onward generally make some statements about it. By focussing on al-Shifā"s life following her migration to Medina, Ibn 'Abd al-Barr creates the impression that she was a respected and influential figure there. He describes her as a woman of sound judgment and excellence (kānat min 'uqală' al-nisă' wa fudalä'ihinna), ${ }^{22}$ and states that the

16 'Izz al-Dīn b. al-Athīr Abū l-Ḥasan 'Alī b. Muhammad al-Jazarī, Usd al-ghāba fì ma' rifat al-ṣahāāba, eds. 'Alī Muḥammad Mu'awwiḍ et al. (Beirut: Dār al-Kutub al-'Ilmiyya, 2003), 7:162; Aḥmad b. 'Alī b. Ḥajar al-'Asqalānī, Al-Iṣāba fì tamyīz al-ṣaḥāba, eds. 'Ādil Aḥmad 'Abd al-Mawjūd and 'Alī Muḥammad Mu'awwị̣ (Beirut: Dār al-Kutub al-'Ilmiyya, 1995), 8:201.

17 Yūsuf b. 'Abdallāh b. Muhammad b. 'Abd al-Barr, Al-Istī̄āb fı̀ márifat al-aṣhāâ, eds. 'Alī Muhammad Mu'awwị̣ and 'Ādil Aḥmad 'Abd al-Mawjūd (Beirut: Dār al-Kutub al-'Ilmiyya, 1995), 4:423.

18 Abū 'Abdallāh Muhammad b. 'Abdallāh al-Ḥākim al-Naysābūrī, Al-Mustadrak 'alā l-Ṣaḥ̂hayn, ed. Ḥamdī al-Dimirdāsh Muhammad (Mecca and Riyadh: Maktaba Nizār Mușțafā al-Bāz, 200o), 7:2463 (Kitāb Márifat al-șahāäba); Ibn al-Athīr, Usd, 7:162; Ibn Ḥajar, Ișāa ba 8:202-203. See also: Abū l-Q̄āsim Sulaymān b. Aḥmad al-Ṭabarānī, Mưjam al-kabīr, ed. Abū Muḥammad al-Asyūṭī (Beirut: Dār al-Kutub al-'Ilmiyya, 2007), 10:319-320.

19 Ibn Sa'd, Țabaqāt, 5:268-270.

$20 \quad$ I.e. an enslaved man whom she had manumitted.

21 Jamāl al-Dīn Abū l-Hajjāj Yūsuf al-Mizzī, Tahdhīb al-kamāl fì asmā’ al-rijāl, ed. Bashār 'Awwād Ma'rūf (Beirut: Mu’assasat al-Risāla, 1992), 35:207; Aḥmad b. 'Alī b. Ḥajar al'Asqalānī, Tahdhīb al-tahdhīb, ed. Mușțafā 'Abd al-Qādir 'Ațā (Beirut: Dār al-Kutub al'Ilmiyya, 1994), 12:379.

Ibn 'Abd al-Barr, Istī̄a $b$, 4:423. This statement is repeated in most of the later biographical 
Prophet granted her a dār, ${ }^{23}$ where she lived with her son Sulaymān. He also recounts that the Prophet used to take his mid-day siesta at al-Shifä"s home, and she kept a mattress and loincloth for him to use while sleeping; her children kept these relics until the later Umayyad caliph Marwān b. al-Hakam (d. 65/685 $)^{24}$ confiscated them, ${ }^{25}$ presumably when he was governor of Medina. Ibn 'Abd al-Barr also relates that when 'Umar was caliph, he consulted her, and occasionally put her in charge of some of the affairs of the market, i.e. apparently in Medina. ${ }^{26}$ (It should be noted here that Ibn 'Abd al-Barr's entry for Sulaymān b. Abī Ḥathma also states that 'Umar put him in charge of the market-more on this presently.) ${ }^{27}$ Al-Shifā' related hadiths, ${ }^{28}$ and in Ibn 'Abd al-Barr's entry, the ruqyat al-namla tradition is presented as part of her biographical persona, as we will see.

What if any historical information about this female figure might these biographical representations provide? The terms used in Ibn Sad's entry (aslamat ... qadiman) denote a person who converted early on in the Meccan phase of Muhammad's preaching. ${ }^{29}$ The phrase "before the hijra" (qabla l-hijra) furthermore directs the audience/reader to avoid mistakenly classifying al-Shifä’’ among the majority of Meccans, who converted after the fall of Mecca once they had little choice in the matter, and there were clear social and material advantages associated with joining Muhammad's community. Nonetheless, several well-known lists of early Muslims do not contain any reference to her. ${ }^{30}$

works consulted for this study; see Ibn al-Athīr, Usd, 7:162; al-Mizzī, Tahdhīb, 35:207; Ibn Ḥajar, Isāba, 8:2o1; Șalāḥ al-Dīn Khalīl b. Aybak al-Ṣafadī, Kitāa al-Wāfì bi-l-wafayāt, ed. Widād al-Qāḍī (Wiesbaden: Franz Steiner Verlag, 1982), 16:168.

23 For the possible meanings of this term, as well as other sources that assert this, see below.

24 For him, see Ibn 'Abd al-Barr, Istīa àb, 3:444-446.

25 Ibn 'Abd al-Barr, Istīāb, 4:423. This also is often repeated in later works; see Ibn al-Athīr, Usd, 7:163; al-Mizzī, Tahdhīb, 35:207; Ibn Ḥajar, Ișāba, 8:201; al-Ṣafadī, Wāfì, 16:168.

26 "wa rubbamā wallā-hā shay'an min amr al-sūq" (Ibn 'Abd al-Barr, Istīâab, 4:424). All of the later biographical sources used here state that 'Umar consulted her (Ibn al-Athīr, Usd, 7:162; al-Mizzī, Tahdhīb, 35:207; Ibn Ḥajar, Ișāba, 8:202; al-Ṣafadī, Wāfı̀, 16:168), but neither Ibn al-Athīr nor al-Ṣafadī (d. 764/1363) mention him giving her any role in the market.

27 Ibn 'Abd al-Barr, al-Istī̄āb, 2:210; Ibn al-Athīr, Usd, 2:547.

28 That he does not mention that she related hadiths is typical of most of Ibn Sacd's entries for early Muslim women who are credited in other sources with having done so; see Asma Sayeed, Women and the Transmission of Religious Knowledge in Islam (Cambridge and New York: Cambridge University Press, 2013), 75 .

29 Miklos Muranyi, "The First Muslims in Mecca: A Social Basis for a New Religion?" in The Life of Muhammad, ed. Uri Rubin (Aldershot: Ashgate Variorum, 1998), 99.

3o See for example Ibn Hishām's (d. 213/833) lists of early converts (Abū Muhammad 'Abd al-Malik b. Hishām b. Ayyūb al-Macāfirī, Al-Sìra al-nabawiyya, eds. Mușțafā al-Saqqā et 
It is difficult to determine what historical basis key features of al-Shifā"s biographical entries compiled by Ibn Sad and Ibn 'Abd al-Barr might have. The isnäd given for a pietistic hadith related in the Musnad ibn Hanbal (d. 241/855) on her authority states that she was "among the women who made the hijra." ${ }^{31}$ A tradition related in al-Bukhārìs (d. 256/870) Adab al-mufrad recounts that when Abū Bakr b. Sulaymān b. Abī Hathma was asked when people began to write the title amir al-mu'minin (Commander of the Faithful), ${ }^{32}$ he related that according to his grandmother al-Shifä- — "and she was among the first women to make the hijra, and whenever 'Umar b. al-Khațtāb, may God be pleased with him, would go to the market he would visit her"33 - when 'Umar was caliph, he requested the governor of Iraq to send him two men who could inform him about conditions there. When these two messengers arrived in Medina, they asked to see the amir al-mu'minin, and from that time onward this title was used in writing. ${ }^{34}$ It is difficult to escape the suspicion that such transmitters' statements about al-Shifā' were intended to identify a rather obscure figure, in order to bolster the authority of the hadith in question - or possibly, to enhance the prestige of Abū Bakr b. Sulaymān b. Abī Hathma by presenting his female ancestor as exceptionally meritorious. ${ }^{35}$

al. (Beirut: Dār al-Kutub al-'Ilmiyya, 2001), 189-198, 238-243, 265-269); Ibn Sa'd, Tabaqāt, 1:285-286; 3:139; see also Shams al-Dīn Muḥammad b. 'Uthmān al-Dhahabī, Siyar a lam alnubalā', eds. Shu'ayb al-Arna’ūṭ and Ḥusayn al-Asad (Beirut: Mu’assasat al-Risāla, 2001), 1:144-145.

31 Ahmad b. Ḥanbal, Musnad al-Imām Aḥmad b. Hanbal, ed. Muḥammad 'Abd al-Salām 'Abd al-Shāfì (Beirut: Dār al-Kutub al-'Ilmiyya, 1993), 6:403.

32 I.e. presumably primarily in correspondence.

33 "wa kānat min al-muhājirāt al-uwal, wa kāna 'Umar ibn al-Khaț̣āb raḍiya 'llāhu 'anhu idhā huwa dakhala l-sūq dakhala 'alayhā." Note however that as this tradition is recounted by al-Ḥākim and Ibn 'Abd al-Barr, this phrase only reads: "wa kānat min al-muhājirāt al-uwal" (and she was among the first women to make the hijra); see al-Ḥākim, Mustadrak, 7:1689 (K. Ma'rifat al-ṣahāâba); Ibn 'Abd al-Barr, Istī̄āb, 3:239.

34 Muḥammad Nāṣir al-Dīn al-Albānī, Șaḥịh Al-Adab al-mufrad li-l-Imām al-Bukhārī (Jubail, Saudi Arabia: Dār al-Ṣiddīq, 1994), 390-391. Al-Albānī judges the isnād of this tradition to be șaḥịh (al-Albāni, Șaḥịh, 391).

35 While al-Zuhrī reportedly stated that Abū Bakr was among the knowledgeable ('ulamä') of the Quraysh, and Ibn Hiibbān included him among the reliable transmitters (thiqāt), he nonetheless does not appear to have been a notably prolific or greatly sought after source of hadiths. Ibn Ḥajar states that he transmitted from seven persons, including his grandmother al-Shifā', and only eight are said to have related hadiths from him (Tahdhīb al-tahdhīb, ed. Mușțafā 'Abd al-Qādir 'Ațā (Beirut: Dār al-Kutub al-'Ilmiyya, 1994), 12:23). He is classified among the Successors; no death date appears to be available for him. 
The assertion that the Prophet allocated a dār to al-Shifā' where she lived with her son Sulaymān ${ }^{36}$ is interesting on several counts. In this context, a "dār" appears to be a compound, made up of rooms or apartments built around a common courtyard, ${ }^{37}$ perhaps including some adjacent farmland as well. ${ }^{38}$ Ibn Shabba (d. 262/875) quotes several traditions that mention this property. According to one:

Al-Shifā' bt. 'Abdallāh b. 'Abd Shams b. Khalaf b. Saddād selected and took possession of her dār; (its entrance is) on al-Hakkākīn road in the (same) neighbourhood. A portion of it went out of her descendants' possession - and they were the Banū Sulaymān b. Abī Hathma al-'Adawīand it came to be for al-Faḍl b. al-Rabī', and a portion of it remained in their hands. ${ }^{39}$

Another tradition appears in Ibn Shabba's chapter on places of prayer (masājid) which the Prophet had used in Medina at one time or another. It lists the $d \bar{a} r$ of al-Shifä' among several such sites, specifying, "The Prophet performed the ritual prayer in the dār of al-Shifā', in the room (bayt) to the right of the entrance to the $d \bar{a} r{ }^{\prime \prime}{ }^{\prime 0}$ Yet another account asserts that he performed the Eid prayer at her $d \bar{a} r{ }^{41}$ However, Ibn Shabba gives the impression that this would have only taken place once, perhaps as a temporary measure soon after the ritual of Eid prayers was established, ${ }^{42}$ while al-Samhūdī (d. 911/1506) says it

36 Ibn 'Abd al-Barr, Istī̄a b, 4:423; Ibn al-Athīr, Usd, 7:162; al-Mizzī, Tahdhīb, 35:207; Ibn Ḥajar, Ișāba, 8:202.

37 Francis Edward Peters, Muhammad and the Origins of Islam (Albany: State University of New York Press, 1994), 299, no. 21 (following Leone Caetani). In similar traditions, Meir Jacob Kister translates dār as "court"; e.g. "Land Property and Jihād: A Discussion of Some Early Traditions," Journal of the Economic and Social History of the Orient 34, no. 3 (1991): 306.

38 For this possibility, see Isaac Hasson, "Contributions à l'étude des Aws et des Hazrăg," Arabica 36 (1989): 7-8.

39 Abū Zayd 'Umar b. Shabba al-Numayrī al-Bașrī, Tārīkh al-Madīna al-munawwara, ed. Fahīm Muḥammad Shaltūt (Beirut: Dār al-Turāth, 1990), 1:248-249; see also: Nūr al-Dīn 'Alī b. Aḥmad al-Mișrī al-Samhūdī, Wafā̉ al-wafā bi-akhbār dār al-Mușțafā, ed. Muhammad Muhyī al-Dīn 'Abd al-Ḥamīd (Beirut: Dār Ị̂yāà al-Turāth al-'Arabī, 1981), 3:881. I would like to thank Walid Saleh for assistance in translating this passage.

40 Ibn Shabba, Tārīkh, 1:73; al-Samhūdī, Wafā, 3:880.

41 "șallā Rasūl Allāh șalla 'llahu alayhiwa sallam al-'id 'inda dār al-Shifă’” (Ibn Shabba, Tārīkh, 1:133-134).

42 The tradition goes on to say that then he prayed it in the Haarrat al-Daws, and finally in the mușallā, where he continued to perform it for the rest of his life (Ibn Shabba, Țärīkh, 1:133-134). See also: al-Samhūdī, Wafä', 3:781. 
means that the Prophet actually led this prayer at the muṣallā, i.e. the site typically used for Eid prayers. ${ }^{43}$ Such apparent efforts to minimise the latter report or to interpret it away may stem in part from its lack of congruence with later ritual practice, or perhaps from puzzlement as to why_if Eid prayers had to be held in a "domestic" space at all—a dār belonging to a senior male Companion would not have been selected.

Muhammad reportedly allocated various pieces of land and property in Medina to certain Companions who had migrated from Mecca, as well as to groups of people, especially after the expulsion of the Banū Nadīir. Such allotments had several political implications: They gave Muhammad some leverage over groups attempting to settle in Medina, as well as a way to reward key followers, and strengthened the position of his fledgling community within Medina's economy. ${ }^{44}$ It can also be said that such grants would not only be a way of giving migrants significant material inducement to remain in Medina, but also of maximising their stake in the successful outcome of Muhammad's community-building venture there.

The statements that the Prophet allocated al-Shifä' a dār could be read as implying that in his eyes, she was a follower whose loyalty was worth rewarding as well as continuing to cultivate, possibly because she was a person with some influence. Nonetheless, the traditions related by Ibn Shabba that mention this $d \bar{a} r$ are textually embedded within a constellation of broader concerns that arose several generations at least after Muhammad's death, and need to be read with these factors in mind. These range from ongoing constructions of Medina as sacred through the memorialisation of particular sites as places where certain storied events occurred or rituals were performed by the Prophet, to the assertion of rights to plots of land in the town by the descendants of various Companions.

That Muhammad is said to have allocated the $d \bar{a} r$ to al-Shifä' herself and that she reportedly lived there with her son Sulaymān who had made the hijra with her while he was a young boy ${ }^{45}$ could suggest that her husband Abū Hathma was not with her in Medina. This might be because he was deceased by that time, or had divorced her, although it seems more likely that his presence goes unmentioned because she was the more prominent of the two. ${ }^{46}$ Whatever the

Al-Samhūdī, Wafă’ 3 :881. He says that this is the case because al-Shifā's dār was near both the mușalla and the market. For a tradition that might portray it as having had a similar location, see below.

44 Kister, "Land property and Jihād," 304-305.

45 Ibn 'Abd al-Barr, Istīāa, 2:210.

46 Abū Ḥathma's full name was 'Abdallāh b. Ḥudhayfa, or possibly 'Adī b. Ka'b b. Ḥudhayfa b. 
case, this grant of property gives the impression that she functioned in Medina as the head of her household — at least, as long as her son was a minor. ${ }^{47}$ While one might infer that given the norms of the time as well as the apparent size of the $d \bar{a} r$, relatives, enslaved persons or clients might also have lived there with her, classical biographers do not discuss this. Apparently, what they wished to highlight is her religious merits, as implied by the Prophet's allocation of a dār to her, where he moreover is said to have visited her. The assertions that he used to take a siesta at her home and that objects he touched were kept as relics by her children serve to further emphasise her merits, which in turn could be taken to reflect well on her descendants. ${ }^{48}$

While biographical works consulted for this study from Ibn Hiibbān's Kitāb al-thiqāt onwards typically state that al-Shifā' related some hadiths, she does not appear to have been credited with very many. There is no chapter of hadiths attributed to her in the musnads of either al-Ṭayālisī (d. 204/818) or al-Humaydī (d. 219/834). While Ahmad b. Hanbal's (d. 241/855) musnad provides such a chapter, it only contains two traditions: One is a version of the ruqyat al-namla tradition, and the other is a pietistic hadith. Al-Ṭabarāni’s (d. 36o/971) Mújam al-kabir ascribes only seven or eight hadiths to her (excluding repetitions). ${ }^{49}$ Interestingly, her name appears in the isnāds of a couple of traditions that deal with written correspondence in the early community. One, which appears in al-Bukhāri’s Adab al-mufrad, has already been discussed above. Another

Tammām b. Ghānim b. 'Abdallāh b. 'Uwayj b. 'Adī b. Ka'b al-'Adawī al-Madanī (Ibn Ḥajar, Tahdhīb, 12:23). It seems that he was an obscure figure about whom few details were preserved; Ibn 'Abd al-Barr for example says nothing about when he converted or made hijra, nor does he mention his participation in any battles (Ibn 'Abd al-Barr, Istĩ āb, 4:195).

47 Interestingly, a tradition recounts that one day at the dawn prayer, 'Umar noticed that Sulaymān was not present; then "Umar went to the market—and Sulaymān's dwelling (maskan Sulaymān) was between the market and the Prophet's mosque-and he passed by al-Shifā', mother of Sulaymān. He said to her, 'I did not see Sulaymān in the dawn (prayer) ...'” (Mālik b. Anas, Muwaț̣a’ al-Imām Mālik—riwāyat Yahyā b. Yahyā al-Laythī (Arabic-English), trans. Muhammad Rahimuddin (Beirut: Îv li-l-Ṭabā'a wa-Nashr, 1985), 132-133 (Kitāb al-Ṣalāt)). This could be interpreted variously: "maskan Sulaymān" could refer here to a room or apartment where he lives within the $d \bar{a} r$ belonging to al-Shifä', or perhaps Sulaymān, evidently no longer a child, is now regarded as the owner of the $d \bar{a} r$, although his mother lives there with him. If the latter is assumed to be the case, then one could infer that she only held the $d \bar{a} r$ in trust for him while he was a minor. Nonetheless, Ibn Shabba's reference to her descendants retaining possession of part of the property suggests that she remained its recognised owner until she died.

48 It should be noted that these distinctions are presented as unusual, yet not as unique to al-Shifā’; cf. the entry for another female Companion, Umm Sulaym bt. Milhān (Ibn Sa‘d, Țabaqāt, 8:467-469). 
is recounted by Ibn Sad in his chapter about the letters that Muhammad reportedly sent to several rulers calling them to Islam. ${ }^{50}$ It is difficult to know what to make of this association between al-Shifā' and written correspondence $^{51}$ (more on this below).

Ibn 'Abd al-Barr's assertion that "Umar sought out her views; he was pleased with her and gave her precedence" 52 seems to imply that not only did he ask for her advice at times - much as he is said to have occasionally consulted women who had certain kinds of experiential knowledge ${ }^{53}$ _ but that he gave her opinions particular weight. Unfortunately, no details are provided, nor is it clear from where Ibn 'Abd al-Barr obtained this information. In the context of this biographical entry, its function seems to be to depict her as a woman with an unusual reputation for intelligence and good judgment. The statement that 'Umar occasionally put her in charge of some of the affairs of the market seems to be intended to further emphasise this. ${ }^{54}$ Presenting al-Shifä' as possessing intellect and discernment bolsters the credibility of the ruqyat al-namla tradition by signalling to the reader/audience that al-Shifä' could be expected to have understood the legal ramifications of transmitting a hadith on a muchdebated topic. 55

Ibn 'Abd al-Barr's entry for al-Shifā' recounts two versions of the ruqyat al-namla tradition. The first simply states: "The Messenger of God said to her, "Teach Ḥafșa ruqyat al-namla as you taught her al-kitāb." This particular

50 Ibn Sacd, Tabaqāt, 1:365. This is a combined report, so it is difficult to determine exactly what portions of this lengthy tradition are ascribed to her specifically. For a study on these letters attributed to Muhammad, see Lecker, "The Preservation of Muhammad's Letters."

$5^{1}$ al-Balādhurī (d. 279/892) includes al-Shifā̄ in his list of literate Meccans; see Dmitri V. Frolov, "The Spread of Literacy in Mecca and Medina at the Time of Muhammad," in The Humanities in Russia: Soros Laureates. The 1994 All-Russia Competition of Research Projects in the Humanities (Moscow: [International Science Foundation], 1997), 136. I would like to thank Sebastian Guenther for this source.

$5^{2}$ "wa kāna 'Umar b. al-Khațậb yuqaddimu-hā bi-l-ra'y wa yarḍā-hā wa yufaḍilu-hā."

53 Mālik, Muwațta', 664 (Kitāb al-Rahn).

54 That Ibn 'Abd al-Barr separately asserts that 'Umar put al-Shifā' and her son Sulaymān in charge of some of the affairs of the market can be interpreted in various ways. It is possible that a post "originally" attributed to al-Shifā' came to be mistakenly ascribed to her son (due to scribal error, or perhaps also in part to later compilers' doubts that 'Umar would give such a task to a woman). The reverse is also possible, though it seems less likely that a role "originally" performed by Sulaymān would erroneously be attributed to his mother. One could even speculate that 'Umar was remembered as directing al-Shifā' to fill in for Sulaymān when necessary—or vice versa.

55 For the impact of transmitters' reputations for legal discernment on the acceptability of hadìths recounted on their authority, see Sayeed, Women and the Transmission, 65, 68, 9697 . 
wording - "al-kitāb" rather than "al-kitāba" —also appears in an elaborated version of the ruqyat al-namla tradition which is quoted by al-Hākim. ${ }^{56}$ This raises the question of what "al-kitäb" connotes here, as well as which wording is older.

In this context, "al-kitāb" could mean "writing,"57 or "the Book," i.e. the Qur'ān. The lector difficilior here appears to be "al-kitāba," as it has an extra letter, and is also more ambiguous. While one can speculate why this tradition would link ruqya to writing, ${ }^{58}$ the connection is not readily apparent. A scribe might presume that "al-kitāba" is a mistake and "correct" it by writing "al-kitāb" (meaning the Qurān), which could seem to make better sense in light of wellknown hadiths advising that qurānic verses be used for healing. ${ }^{59}$ Also, the fact that al-Khațāaī (d. 388/998) states that the ruqyat al-namla tradition is evidence in favour of the view that teaching women how to write is not a reprehensible act (ghayr makrūh) ${ }^{60}$ could suggest an additional motive for such a scribal emendation - in order to reduce this tradition's value in this debate by making it unclear whether the Prophet is approvingly mentioning that alShifä̉ had taught Hafșa how to write, ${ }^{61}$ or that she instructed her in (some of the contents of) the Qur'ān. ${ }^{62}$ While it seems more likely that "al-kitāab" is the older wording, it may never be possible to determine whether this is the case.

$5^{6}$ al-Ḥākim, Mustadrak, 7:2462 (Kitāb Márifat al-șaḥāba).

57 For the primary meaning of "kitāb" in the qurānic text as "writing," see Daniel Madigan, The Qur'ân's Self-Image: Writing and Authority in Islam's Scripture (Princeton, NJ and Woodstock, Oxfordshire: Princeton University Press, 2001), 82.

$5^{8}$ For example, one could speculate that the tradition is intended to imply that much like writing, ruqya is a technical skill that some people need to master in order to benefit the community, or that the point is the emphasise ruqya's permissibility by linking it to writing, which has an aura of sacredness due to its association with scriptures. It is also possible that ruqya and writing are linked here due to (controversial) healing and protection practices involving writing - more on these presently.

59 See for example Ibn Wahb, al-Jāmic', 2:791-794; Abū Dāwūd, Sunan, 3:396-398 (Kitāb alTibb).

6o Abū Sulaymān Ḥamd b. Muhammad al-Khațțābī, Macălim al-sunan: sharh Sunan Abī Dāwūd, ed. 'Abd al-Salām 'Abd al-Shāfĩ Muḥammad (Beirut: Dār al-Kutub al-'Ilmiyya, 1996), 4:210.

61 While little is known at present about the origins and development of the medieval debate about whether women should be taught to write, available evidence appears to suggest that this was not a question that attracted much concern before the fourth/tenth century; see Aisha Geissinger, Gender and Muslim Constructions of Exegetical Authority: A Rereading of the Classical Genre of Qur'ān Commentary (Leiden: Brill, 2015), 248-255.

62 For a critical examination of a tradition that depicts 'Umar telling Hafșa to verify the "correct" reading of a qur'ānic verse see Aisha Geissinger, "No, a Woman Did Not 'Edit the Qurān': Towards a Methodologically Coherent Approach to a Tradition Portraying a Woman and Written Qur'ānic Materials," Journal of the American Academy of Religion 85, no. 2 (June 2017): 416-445. 
The second version of the ruqyat al-namla tradition recounted by Ibn 'Abd al-Barr is an elaborated one, which recounts on al-Shifä's authority that she did incantations in pre-Islamic times; she had also pledged allegiance to Muhammad prior to his hijra. After she had migrated to Medina, she went to the Prophet and said that she "used to perform ruqya using the incantations of the jāhiliyya," and asked if she could demonstrate these to him. He assented, and among those that that she demonstrated was the one for namla. The Prophet responded:

Perform incantation in the following way, and teach it to Hafșa: "In the name of God. Prayers firm, forceful, seeking refuge from their mouths, that they harm no one. O God, remove the harm, cure the people." Recite this seven times over a saffron twig, and put it in a clean place; then rub it on a stone along with vinegar made of wine from Thaqif, and daub it on the namla. ${ }^{63}$

In this tradition — which al-Hâkim several decades earlier had already presented as part of her biography ${ }^{64}$ — while al-Shifā"s commitment to monotheism dates from well before the hijra, she does not initially integrate her knowledge of pre-Islamic healing practices, which presumably involved the invocation of pagan deities or other supernatural beings, with her new beliefs. Following her migration to Medina, however, she decides to do so, and requests Muhammad's verdict. His response is to counter her enactment of these practices with a performance of his own, by modelling an incantation that accords with monotheistic sensibilities. Not only this, but the Prophet provides directions as to the preparation of certain ingredients to use when treating namla. At this point in the text, any illusion that a contemporary reader might have that Ibn 'Abd al-Barr is simply presenting reports he received about a woman who lived in north-west Arabia at the dawn of Islam dissipates in the face of step-by-step directions apparently meant to enable readers/audiences of his own time and place to perform a healing incantation in a manner that he deems doctrinally acceptable.

63 Ibn 'Abd al-Barr, Istī̄āb, 4:424; similarly, Ibn al-Athīr, Usd, 7:162-163; Ibn Ḥajar, Ișāba, 8:202. Ibn Hajar attributes the anecdote and the wording of the incantation to different authorities, which suggests that the latter was a later addition.

64 al-Ḥākim, Mustadrak, 7:2462-2463 (Kitāb Márifat al-ṣahāba). Several centuries later, alDhahabì (d. 748/1348) stated that one of the transmitters is unknown. 


\subsection{Provenance and Early Transmission: The Available Evidence}

At least one version of the ruqyat al-namla tradition appears in nine Sunni hadith compilations. In addition to those already mentioned, ${ }^{65}$ these include: the Mușannaf of Ibn Abī Shayba (d. 235/849), the Sunan Abī Dāwūd (d. 275/ 889), and al-Nasā'ì's (d. 303/915-916) Sunan al-kubrā, as well as al-Bayhaqì's (d. 458/1066) collection of the same name. It is also found in the Sharh ma'āni al-āthār of al-Ṭahāwī (d. 321/933). Some of these sources provide more than one version of this tradition. In the following analysis of the isnāds, which is based on the methodology pioneered by Gautier H.A. Juynboll ${ }^{66}$ as well as its further development by Najam Haider, ${ }^{67}$ I have grouped these versions into two main categories: 68

(1) The "ruqya only" category, meaning those versions that simply direct an unnamed woman/al-Shifā' to teach another woman (identified as Hafșa, either in the tradition itself or occasionally by a transmitter) her ruqya, e.g. “... there was a woman with her [Hafṣa] — she was called al-Shifä’performing an incantation against namla. The Prophet said, 'Teach it to Hafṣa.' "69 “Teach Hafṣa your ruqya."70

(2) The "writing" category, meaning those versions that also mention having taught Hafșa writing (or possibly, the Book), e.g. “... The Messenger of God came in when I was with Hafșa, and he said to me, 'Won't you teach her ruqyat al-namla, just as you taught her how to write?' "71

65 I.e. Ibn Wahb's Jāmi', the Mușannaf 'Abd al-Razzāq, the Musnad Ahmad b. Hanbal, alṬabarānīs Mu'jam al-kabìr, and al-Ḥākim's Mustadrak.

66 For a summary of this, see the introduction to his Encyclopedia of Canonical Hadith (Leiden: Brill, 2007).

67 As demonstrated in his article, "The Geography of the Isnäd: Possibilities for the Reconstruction of Local Ritual Practice in the 2nd/8th Century," Der Islam 9o, no. 2 (2013): 306346.

68 I have not carried out an isnād analysis of versions in the third category-those that discuss al-Shifā"s ruqya in pre-Islamic times, how she asked the Prophet permission to practice it, the words of the incantation, etc., primarily because traditions of this type likely constitute later elaborations upon an earlier core.

69 Ibn Ḥanbal, Musnad, 6:318; Abū 'Abd al-Raḥmān Aḥmad b. Shu'ayb al-Nasā̄ī, Al-Sunan alkubrā, ed. Abū Anas Jādallāh b. Ḥasan al-Khaddāsh (Riyadh: Maktabat al-Rushd, 20o6), 2:1167 (Kitāb al-Ṭibb); al-Ṭabarānī, Mưjam, 10:32o; al-Ḥākim, Mustadrak, 8:2938 (Kitāb alRuqya wa l-tamā’im); similarly, Abū Ja far Aḥmad b. Muhammad b. Salāma b. 'Abd al-Malik al-Azdī al-Mișrī al-Ṭahāwī, Sharh ma ānī al-athār, ed. Ibrāhīm Shams al-Dīn (Beirut: Dār al-Kutub al-'Ilmiyya, 2006), 4:149 (Kitāb al-Karāha).

$70 \quad$ Ibn Abī Shayba, Mușannaf, 8:30-31; al-Ṭabarānī, Mújam, 10:32o.

71 Abū Dāwūd, Sunan, 3:393 (Kitāb al-Ṭibb); Ibn Ḥanbal, Musnad, 6:403; al-Nasā̄ì, Sunan, 2:1167 (Kitāb al-Ṭibb); al-Ṭaḥāwī, Sharh, 4:149 (Kitāb al-Karāha); Abū Bakr Aḥmad b. al- 


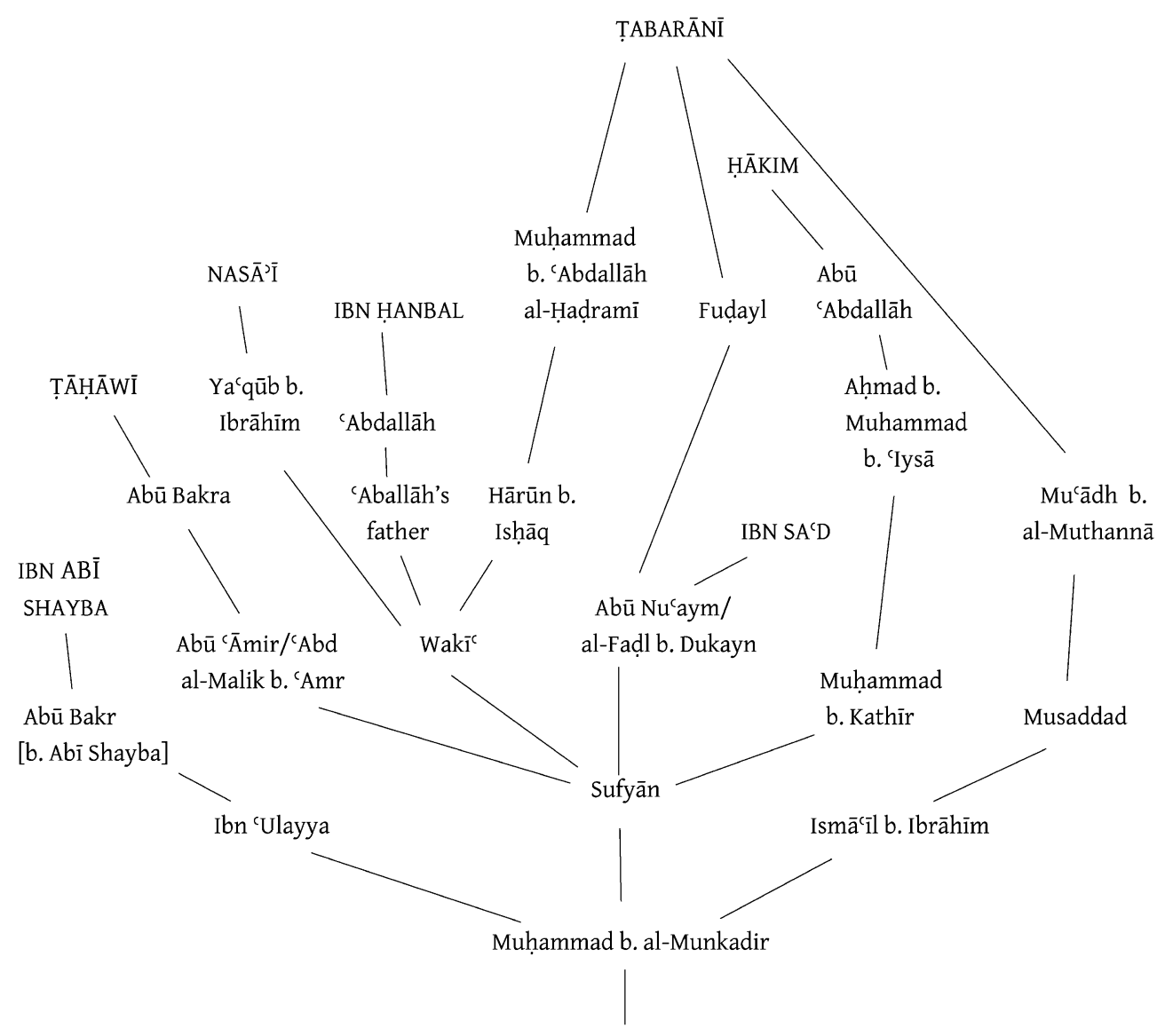

Abū Bakr b. Sulaymān b. Abī Ḥathma

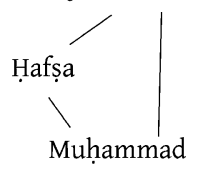

FIGURE 10.1 The "ruqya only" category

A comparison of the isnāds of figures 1 and 2 suggests several things. First of all, it appears that Sufyān al-Thawrī (d. 161/778, Basra), as the common link in most of the isnāds of versions belonging to the ruqya alone category, seems to

Ḥusayn b. 'Alī al-Bayhaqī, Al-Sunan al-kubrā, ed. Muhammad 'Abd al-Qādir 'Ațā (Beirut: Dār al-Kutub al-'Ilmiyya, 2010), 9:587 (Kitāb al-Dahạayā). Similarly, Ibn Abī Shayba, Muṣannaf, 8:31 (Kitāb al-Tïibb); al-Ṭabarānī, Mưjam, 10:318-319. 
Abū Zur'a — ȚABARĀNĪ

$\mathrm{Abū} \mathrm{Nu}^{\mathrm{c} a y m}$

Musaddad

Mucādh b. Muthannā
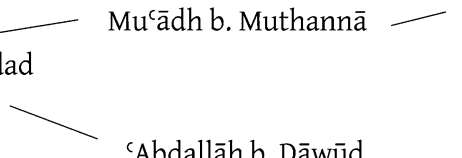

'Abdallāh b. Dāwūd

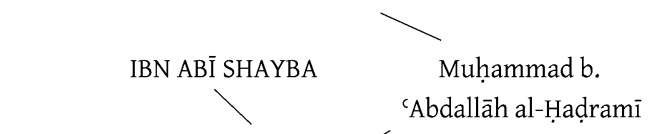

IBN ḤANBAL Abū Bakr

'Abdallāh al-Ḥaḍramī

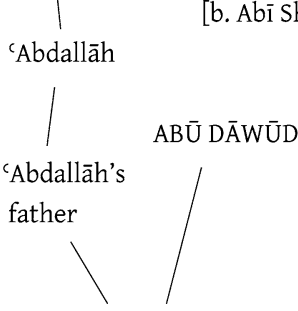

Ibrāhīm b. Mahdī

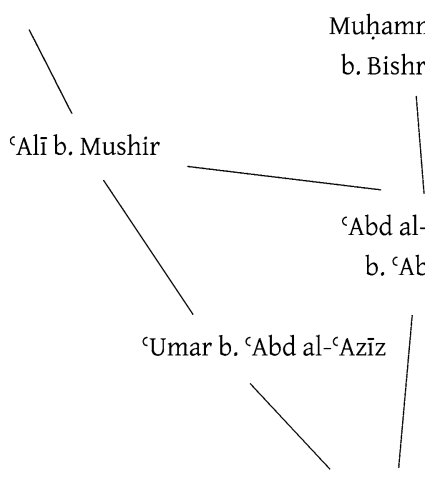

Ṣālị̣ b. Kaysān
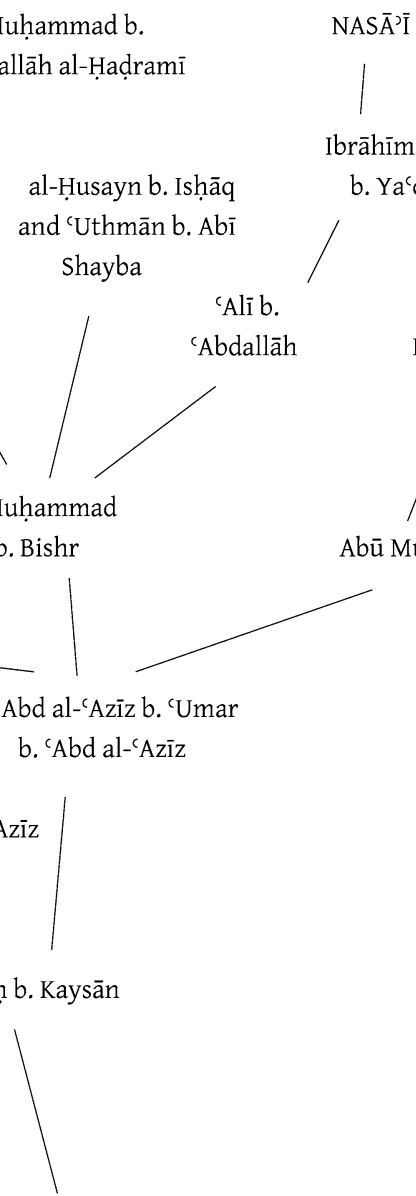

\section{TAHẠĀWI}

BAYHAQİ

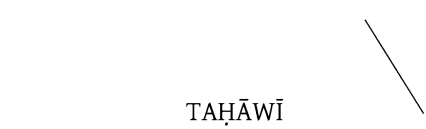

Abū Nașr and Abū Bakr

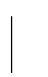

$\mathrm{Abu} \bar{c}^{\mathrm{c}} \mathrm{Amr}$
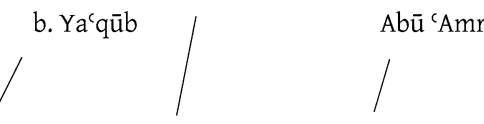

'Alīb.

Ibn al-

Isbahānī

'Abdallāh

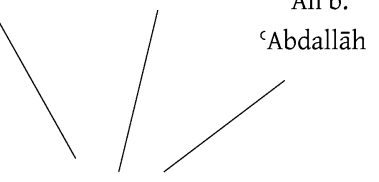

Muhammad

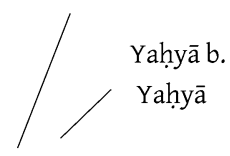

Ibrāhīm b. 'Alī

b.

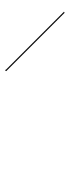

Abū Mu'āwiya

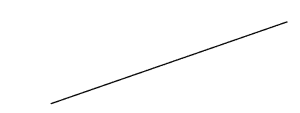

bd al-'Azīz b. 'Umar

. 'Abd al-'Azīz

'ABD AL-RAZZĀQ

IBN WAHB
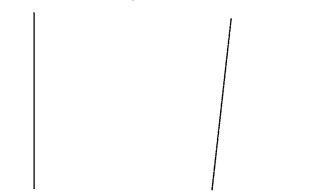

Ma'mar

Yūnus b. Yazīd
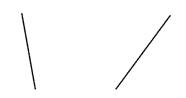

Ibn Shihāb al-Zuhrī

Abū Bakr b. Sulaymān b. Abī Ḥathma

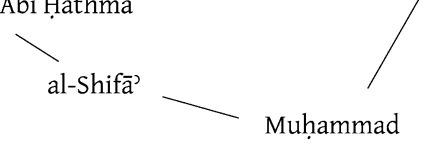

FIGURE 10.2 The "writing" category 
have played a noteworthy role in their circulation in southern Iraq. But versions belonging to the writing category reportedly go back to one of two Syrian common links —either to 'Abd al-'Azīz b. 'Umar b. 'Abd al-'Azīz (d. after 140/757), ${ }^{72}$ or to Ibn Shihāb al-Zuhrī (d. 124/742). Second, the partial common links of versions from both categories-Muhammad al-Munkadir (d. ca. 130/747) ${ }^{73}$ in the case of the ruqya alone category, and Șālih b. Kaysān (d. ca. 141/758) $7^{74}$ for the writing category—are Medinans. Nonetheless, after Abū Bakr b. Sulaymān b. Abī Hathma there is no overlap among the isnāds of these two categories. If the possibility that these attributions to him have some historical basis is to be entertained, this would suggest that he recounted the ruqyat al-namla tradition in different ways. However, given the different regional associations of the two categories, it seems more probable that these distinctions developed once the tradition had made its way to Syria and Iraq.

The phrase, "just as you taught her writing (or perhaps, the Book)" is a subordinate clause in versions of the ruqyat al-namla tradition within which it appears. Its function is apparently to rhetorically legitimate the disputed practice of ruqya by drawing an implicit link between it and writing (or, in the case of the versions that read "al-kitāb," possibly between ruqya and certain qur'ānic verses). Writing is often associated with scriptures and religious knowledge in these texts, and both incantations and writing were used together in certain types of healing practices, such as when qurānic verses were written, dissolved in water, and the resulting liquid administered to sick persons or women in labour. ${ }^{75}$ It is possible that the circulation of the "ruqya only" category in Iraq in the mid-second/eighth century could be related to two factors: First, early debates about recording any text in writing aside from the Qurān were reportedly particularly intense there. ${ }^{76}$ Second, the use of writing in amulets and healing practices is said to have been strongly opposed by a number of

72 He was a son of the Umayyad caliph, 'Umar b. 'Abd al-'Azìz. Hadìth critics had varying views of his reliability as a transmitter (Ibn Hajar, Tahdhīb, 6:307-308).

73 Muhammad b. al-Munkadir b. 'Abdallāh b. al-Ḥudayr b. 'Abd al-'Uzzā b. 'Āmir b. al-Ḥārith b. Ḥāritha b. Sa'd b. Taym b. Murra al-Taymī was a Successor (Ibn Ḥajar, Tahdhīb, 9:407409).

74 He was a Successor, one of the fuqahä' of Medina who collected hadiths, and was a tutor to the children of the Umayyad caliph, 'Umar b. 'Abd al-'Azīz (Ibn Hiibbān, Thiqāt, 3:444; Shams al-Dīn Muḥammad b. Aḥmad b. 'Uthmān al-Dhahabī, Tārīkh al-Islām wa-wafayāt al-mashāhīr wa-l-a'lām, ed. 'Umar 'Abd al-Salām Tadmurī (Beirut: Dār al-Kitāb al-'Arabī, 2001), $178 \mathrm{ff}$., years 141-160AH).

75 E.g. Ibn Abī Shayba, Mușannaf, 8:23-25 (Kitāb al-Ṭibb).

76 Gregor Schoeler, "Oral Torah and Ḥadīth: Transmission, Prohibition of Writing, Redaction," in Hadīth: Origins and Developments, ed. Harald Motzki (Aldershot: Ashgate Variorum, 2004), 73-74. 
religious authorities in Iraq as well. ${ }^{77}$ One could infer that in such a context, the phrase "... just as you taught her writing" would not be an effective way to convey the notion that the practice of ruqyat al-namla is uncontroversial, so it was never added — or perhaps, it was dropped. But the reasons for this geographical variation are unclear.

To sum up the findings thus far: This investigation has turned up more questions than answers. The "original" form of the ruqyat al-namla tradition might have been about two unnamed women rather than either al-Shifā' or Hafșa. The representations of al-Shifā' in the biographical works consulted for this study have evidently been shaped to varying extents by various and fluctuating concerns, ranging from those of hadith critics, to land claims in Medina made by persons claiming her as their ancestor, as well as by the association of the ruqyat al-namla tradition with her. It was not possible to verify any biographical details about this female figure, as information was either lacking, or it was unclear whether any seemingly corroborating items actually had their origins in the ruqyat al-namla tradition. The isnād analysis indicates that in the second/eighth century, two versions of this tradition, one mentioning ruqya only, and the other ruqya with writing, circulated in Iraq and Syria respectively. The historical origins of the reference to writing- "just as you taught her writing (al-kitāba)" (or, in a few instances noted above, possibly "the Book") — are unclear, though "al-kitāba" seems more likely to be the "older" wording.

Can the ruqyat al-namla tradition in and of itself provide evidence that alShifä was literate- or for that matter, if Ḥafșa was? In view of all of the problems discussed above relating to the "original" form of this tradition, as well as where the reference to writing came from, the answer appears to be in the negative. It should also be kept in mind that in the hadith compilations arranged by subject as they have come down to us and that contain one or more versions of the ruqyat al-namla tradition, these most often appear in sections or chapters that discuss the subject of ruqya and various allied practices meant to provide supernatural healing and protection. Significantly, they do not appear in chapters or sections that discuss knowledge ( $\mathrm{i} / \mathrm{lm}$ ), writing, or related topics. This suggests that for the compilers (and/or redactors) of these works, the ruqyat al-namla tradition was thought to be primarily relevant to debates about the legal status of incantations; the reference to writing found in some versions would seem to have often been regarded by them as primarily rhetorical. 
Other potentially corroborating evidence has been mentioned above:(1) The presence of al-Shifā' in the isnāds of a couple of traditions discussing written correspondence in the early community, which could be interpreted as indicating that she was literate, so that she might credibly be presumed to have been aware of and perhaps interested in the letters sent by the Prophet or the caliph; (2) al-Balādhurì's mention of al-Shifā̄ in a list of literate Meccans. While these two items could furnish possible starting points for further research into this question, at this point it is unclear whether these isnāds and/or al-Balādhurī simply reflect the assumption of her literacy on the basis of the ruqyat al-namla tradition.

It would be possible to end our investigation here, with a list of historical uncertainties. But to do so would forgo an opportunity to consider the question — which I would argue is actually more consequential—suggested by the quotation of this tradition in a noteworthy number of classical sources, only some of which have been discussed above: Why would a tradition attended by such ambiguities not only be cited in a number of sources, but discussed repeatedly from various angles, for centuries?

\section{Part II: Ongoing Processes of Translation: Shifting Meanings of the ruqyat al-namla Tradition}

In the various versions of the ruqyat al-namla tradition discussed above, Muhammad (along with the two female figures) is depicted within a first/seventh century Medinan context. Yet, at the same time, the authors of the sources which quote these different versions also position the Prophet's interchange with al-Shifā' as speaking to their own times, places, and concerns. ${ }^{78}$ The histories of reception and interpretation of the ruqyat al-namla tradition vividly illustrate some of the mechanisms that enabled such processes of translation, as well as some of the controversies that drove them.

The practice of incantation is arguably endorsed by the last two süras of the qurānic text itself; interestingly, they came to be associated with a story in which Muhammad himself was bewitched by a Jewish man in Medina, Labīd $b$.

78 For the role of hadiths in the construction of the life of Muhammad (as well as of his Companions) as paradigmatic and pre-eminently authoritative, see for example William Graham, "Traditionalism in Islam: An Essay in Interpretation," in Islamic and Comparative Religious Studies: Selected Writings, ed. William Graham (Farnham, Surrey: Ashgate, 2010), $16-26$. 
al-A'șam, and the spell was finally undone by the recitation of these two sūras. ${ }^{79}$ The ways that incantation is often portrayed in hadiths also suggests that it was long-established popular practice in Arabia as well as in the conquered territories in a variety of everyday situations, whether for dealing with fever, snake-bite, scorpion sting, severe pain, or even a mule with a propensity for bolting. It is presented as a way for women to heal sickly children, as well as for aiding mothers in childbirth. ${ }^{80}$ Nonetheless, a number of the hadith collections referenced above indicate that in the second/eighth and third/ninth centuries, whether or not incantations (as well as a number of other healing or protective practices) could be deemed religiously acceptable was a topic that occasioned considerable debate among religious scholars. This controversy served as a vehicle for the expression of imperial anxieties about Muslim identity, internal and external communal boundaries, as well as social and cosmic order.

As Ibn Qutayba (d. 276/889) indicates, different theological factions of his time disputed about the practice of ruqya in order to assert broader claims. Some Mu'tazilites reportedly dismissed it as a method of healing on rationalist grounds. They also pointed out that while some of the hadiths on the topic of incantation permit it, others prohibit it, which in their view was just one example among many as to why hadiths could not serve as an authoritative source. ${ }^{81}$ Similarly, discussions as to whether the use of incantations would constitute failing to rely on God alone for protection or cure, or an effort to avoid what God has destined ${ }^{82}$ were part of wider disagreements among Sunnis about the emerging doctrine of qadr (the divine decree). Utilising the ruqyat al-namla tradition as a proof-text in such debates (as Ibn Qutayba for example did) was one way that Muhammad could be made present, so that he could address theological controversies which took place well after his passing.

79 E.g. Muqātil b. Sulaymān b. Bashīr al-Azdī, Tafsīr Muqātil b. Sulaymān, ed. Aḥmad Farīd (Beirut: Dār al-Kutub al-'Tlmiyya, 2003), 3:537. For a study of this tradition, see Michael Lecker, "The Bewitching of the Prophet Muhammad by the Jews: A Note a propos 'Abd alMalik b. Habīb's Mukhtașar fíl-țibb," in Jews and Arabs in Pre- and Early Islamic Arabia, ed. Michael Lecker (Aldershot and Burlington, vT: Ashgate Variorum, 1998), 561-569.

8o E.g. Mālik, Muwațta', 817-820 (Kitābal-Jāmi'); Ibn Wahb, Jāmi', 2:779-783 (Fül-ruqya); 'Abd al-Razzāq, Muṣannaf, 11:18, 20 (Kitāb al-Jāmic); Ibn Abī Shayba, Muṣannaf, 8:23 (Kitāb alTibb).

81 Abū Muḥammad 'Abdallāh b. Muslim Ibn Qutayba, Ta’wūl mukhtalifal-ḥadīth, ed. Muḥammad Nāfic al-Mușțafā (Amman: Dār al-Bashīr, and Beirut: Mu’assasat al-Risāla, 2004), 6o8614 .

82 E.g. 'Abd al-Razzāq, Muṣannaf, 11:18 (Kitāa al-Jāmic); al-Ṭahāwī, Sharh, 4:148-15o (Kitāb alKarāha). 
While such theological debates played a role in negotiating boundaries within the community, discourses about incantation were also one way to map distinctions between Muslims and Others. A number of religious authorities in the first few centuries of Muslim history (as well as later) were concerned with differentiating between rituals that they regarded as religiously legitimate, and "magic" (sihrr), and vigorously debated which category incantations and other allied healing or protective practices belonged to. ${ }^{83}$ Some feared that incantation was too reminiscent of practices associated with religious Others-not only Others of the past such as pre-Islamic Arab pagans, who had reportedly performed such rituals, invoking their deities or other supernatural beings, ${ }^{84}$ but monotheistic Others still existing in the present, such as Jews, to whom some Muslims might turn for healing. 85

Jurists discussed the various hadiths dealing with incantation as well as other healing practices in detail, attempting to carefully distinguish between practices they deemed acceptable and impermissible. ${ }^{86}$ Nonetheless, as a popular practice that seems to have often been carried out in "domestic" contexts, incantation was effectively beyond their supervision or control. As such, discourses about ruqya were one way to express anxieties about the stability of "proper" religious and social hierarchies, while also reiterating and affirming the latter.

Gendered figures and symbols served as particularly potent vehicles for such delineations. This dynamic is particularly apparent in traditions regarding spells that bring about impotence-a problem that the Prophet himself is said to have faced ${ }^{87}$-as well as traditions about female slaves bewitching

83 For an overview of some of these debates, see Travis Zadeh, "Magic, Marvel, and Miracle in Early Islamic Thought," in The Cambridge History of Magic and Witchcraft in the West from Antiquity to the Present, ed. David Collins (New York: Cambridge University Press, 2015), 235-267; Michael W. Dols, "The Theory of Magic in Healing," in Magic and Divination in Early Islam, ed. Emilie Savage-Smith (Aldershot: Ashgate Variorum, 2004), 87-101. As both Zadeh and Dols point out, attempts to differentiate (legitimate) "religion" from "magic" (with the latter identified with heresy, superstition, etc.) are theological and also culturally bound.

84 Ibn Wahb, Jāmi', 2:778 (Fì l-ruqya); 'Abd al-Razzāq, Mușannaf, 11:16 (Kitāa al-Jāmi'); Ibn Abī Shayba, Muṣannaf, 8:14 (Kitāb al-Tịbb).

85 Mālik, Muwatța', 820-821 (Kitāb al-Jāmic); Abū Dāwūd, Sunan, 3:392 (Kitāb al-Tiibb). For these and other similar traditions, see Uri Rubin, "Muhammad the Exorcist: Aspects of Islamic-Jewish Polemics," in Muhammad the Prophet and Arabia, ed. Uri Rubin (Farnham, Surrey: Ashgate Variorum, 2011), 107-108.

86 See for example al-Ṭahāwī, Sharh, 4:140-153 (Kitāb al-Karāha).

87 'Abd al-Razzāq, Muṣannaf, 11:13 (Kitāb al-Jāmi' ${ }^{c}$. Some versions of the story of Muhammad's bewitchment referred to above present Labid's daughters as the ones who cast the 
the free women who owned them, sometimes with the hope of killing the latter and thereby gaining their freedom. ${ }^{88}$ In such traditions, the "correct" and divinely willed social hierarchies which place men above women and free persons above the enslaved are graphically inverted, as men's and free women's performances of power are rendered ineffective by supernatural means beyond their control — though tellingly, this state of affairs proves to be only temporary.

It is against this complex background that the question of what type of cure or benefit ruqyat al-namla is supposed to effect was discussed and debated. That there was some disagreement on this question is apparent from gharīb al-hadith works, as well as some later hadith compilations and commentaries. Debates about its meaning have the paradoxical effect of emphasising Muhammad's location in the first/seventh century Arabian past (as this expression was apparently already obscure in the late second/eighth century), ${ }^{89}$ and seeming to bridge this gap of time and space by nonetheless rendering it comprehensible. The multiple meanings attributed to this expression also enable Muhammad to seemingly address several different issues.

In his gharīb al-hadith work, Abū 'Ubayd al-Qāsim b. Sallām (d. 224/838) quotes the grammarian al-Așmaì (d. 213/826) as saying that "al-namla" refers to sores that appear on the sides of the body ${ }^{90}$ — shingles, perhaps? ${ }^{91} \mathrm{Ibn}$ Qutayba concurs with this explanation, ${ }^{92}$ which is also quoted later by alHākim and al-Bayhaqī. ${ }^{93}$ However, Abū 'Ubayd also goes on to say that "al-

spell. There is a long history of association of women with certain types of magic thought to bring about various sexual ends, including male impotence; see for example: David Frankfurter, "The Social Context of Women's Erotic Magic in Antiquity," in Daughters of Hecate: Women and Magic in the Ancient World, eds. Kimberly Stratton and Dayna Kalleres (Oxford and New York: Oxford University Press, 2014), 319-339. I would like to thank Kimberly Stratton for this source.

88 'Abd al-Razzāq, Mușannaf, 10:180-181, 183 (Kitāb al-Luqța).

89 Walid Saleh suggests that it might have "originally" meant an incantation intended to remove or guard against infestations of ants from a house, but that in any case, early grammarians may have simply been presenting their own best guesses as to what ruqyat al-namla is (personal communication, November 2015).

9o "hiya qurūḥn takhruju fì al-janb wa-ghayrihi" (Abū 'Ubayd al-Qāsim b. Sallām al-Harawī, Kitāb Gharīb al-hadìth, ed. Ḥusayn Muḥammad Sharaf (Cairo: Al-Hay'a al-Āmma li-Shu'ūn al-Muțābic al-Amīriyya, 1984), 1:217).

91 Juynboll translates "namla" as "pustules" (Juynboll, Encyclopedia, 39), while Lecker renders it as "small pustules" (Lecker, "The Preservation of Muhammad's Letters," 6, no. 35).

92 Ibn Qutayba 'Abdallāh b. Muslim, Gharīb al-ḥadīth, ed. 'Abdallāh al-Jabbūrī (Baghdad: alJumhuriyya al-'Irāqiyya Wizārat al-Awqāf Iḥyā’ al-Turāth al-Islāmī, 1977), 2:620.

93 al-Ḥākim, Mustadrak, 7:2463 (Kitāb Márifat al-ṣaḥāba); al-Bayhaqī, Sunan, 9:585 (Kitāb al-Ḍahāàa). 
namla" means "namima" (slander).${ }^{94}$ The inclusion of the ruqyat al-namla tradition in chapters or sections that address healing in a number of the hadith collections discussed above strongly suggests that in the opinion of their compilers, "namla" refers to some sort of physical ailment. However, the second definition given by Abū 'Ubayd seems to indicate that some held that ruqyat al-namla is intended to offer protection from a blameworthy trait.

Building upon the power relations depicted in this hadith, in which a male religious and political leader (and household head) supervises the instruction given to his wife by a woman from his community, some later medieval gharib al-hadith works further elaborate on this latter line of interpretation. AlZamakhsharī (d. 538/1144) — who quotes al-Așmaî's explanation of what the word "namla" means-nonetheless asserts that the incantation the Prophet instructed al-Shifā" to teach Hafșa was as follows: "The bride celebrates. She holds sway, and applies kohl; she may do anything, except disobey her husband." ${ }^{95}$ Majd al-Dīn Ibn al-Athīr (d. 606/1210) elaborates, stating that it is said (qüla) that the ruqyat al-namla in question is a joke or a riddle that women tell, "and whoever hears it knows that it is (just) words that neither (bring) harm nor benefit." According to him, Muhammad instructed al-Shifā̄ to teach Ḥafșa this ruqya (i.e. "The bride celebrates ...") in order to rebuke his wife for divulging the secret that he had confided to her. ${ }^{96}$

In the explanation credited to al-Așma'ī, ruqyat al-namla is intended to heal a physical ailment; to the extent that the reader/audience believes that this incantation is efficacious, then al-Shifā' is presumed to be able to heal through it, and also to teach Hafșa how to do so. In that case, it is depicted as words of power, ${ }^{97}$ which might well enable a person who knows it to garner status

94 Abū 'Ubayd, Gharīb, 1:218. However, Ibn al-Jawzī (d. 597/1201) quotes the definition attributed to al-Așmaī for "al-namla," and states that "al-numla" means namìma, slander (Abū l-Faraj 'Abd al-Raḥmān b. 'Alī b. Muhammad b. 'Alī b. al-Jawzī, Gharīb al-ḥadīth, ed. 'Abd al-Mu'țī Amīn Qal'ajī (Beirut: Dār al-Kutub al-'Ilmiyya, 2004), 2:438).

95 Jār Allāh Maḥmūd b. 'Umar al-Zamakhsharī, Al-Fä̉i fígharīb al-hadīth, eds. Muhammad Abū al-Faḍl Ibrāhīm and 'Alī Muḥammad al-Bajāwī (Cairo: 'Iysā al-Bābī al-Ḥalabī, 1971), 4:26. Uri Rubin draws attention to this interpretation of al-Zamakhshari’s (Uri Rubin, "Hafșa," Encyclopaedia of the Qur'ān (Leiden: Brill, 2001), 2:398).

96 Majd al-Dīn Abū l-Sacādāt al-Mubārak b. Muḥammad b. al-Athīr al-Jazarī, Al-Nihāya fì gharīb al-ḥadīth wa-l-athar, eds. Ṭāhir Aḥmad al-Zāwī and Maḥmūd al-Ṭanāḥī (Cairo: 'Iysā al-Bābī al-Ḥalabī, 1963), 5:120. The "secret" referred to here is an allusion to an incident famously mentioned in Qurān 66: 1-5, in which Muhammad spoke in confidence about an unspecified matter to an unnamed wife, but she informed a co-wife about it, and some sort of crisis ensued. Hafșa is typically identified as the wife who divulged the secret (e.g. Muqātil, Tafsìr, 3:376).

97 For the gendering of access to words of power in classical qurānic exegesis, see Geissinger, Gender, 44-47. 
through healing or teaching others to do so-though their transmission and utilisation are clearly subordinated to the Prophet's approval. The interpretation given by al-Zamakhsharī (and rather dubiously elaborated upon by Majd al-Dīn Ibn al-Athīr), however, re-presents ruqyat al-namla as words that more starkly affirm "correct" gender hierarchies, as women jokingly remind brideswho might be tempted to use their bewitching attractiveness in order to assert themselves with their new husbands—of their "proper" place.

\section{Conclusion}

The ruqyat al-namla tradition cannot be treated as a neutral vessel of information. Rather, it is a polemical text, which is primarily designed to address debates in the second/eighth and third/ninth centuries as well as later about the legal status of healing or protective incantations, as well as the associated imperial anxieties about religious identity, internal and external boundaries, and social as well as cosmic order.

Most versions of this tradition as we have it today (complete with transmitters' interjections identifying the women involved) present the Prophet asking al-Shifā’ to teach his wife Hafșa how to perform this incantation. In this depiction, Muhammad is both located in his household in first/seventh century Medina, yet at the same time vividly made present in theological, legal, grammatical, and other debates in Iraq, Syria, Egypt and elsewhere.

The ruqyat al-namla tradition is but one of a number of hadiths dealing with allied healing or protective rituals that were apparently intended to bring these within the ambit of Muslim custom by rendering them compatible with monotheism and a component of the sunna, at least on a rhetorical-textual level (though how this might have affected lived practices is quite another matter).

\section{Acknowledgements}

I would like to thank the conference attendees for their observations, as well as the editors for their very thought-provoking comments and questions. My thanks also go to Walid Saleh and Johannes Wolfart for helpful conversations about method. Any errors of fact or interpretation are mine alone. 


\section{Bibliography}

'Abd al-Razzāq b. Hammām al-Ṣanānī. Al-Muṣannaf. Edited by Ḥabīb al-Raḥmān alA‘ẓamī. 11 vols. Beirut: al-Maktab al-Islāmī, 1970-1972.

Abū Dāwūd Sulaymān al-Ash'ath al-Sijistānī. Sunan Abī Dāwūd. Edited by Ṣidqī Muḥammad Jamīl. 4 vols. Beirut: Dār al-Fikr, 1994.

Abū 'Ubayd al-Qāsim b. Sallām al-Harawī. Kitāb Gharīb al-ḥadīth. Edited by Ḥusayn Muhạmmad Sharaf. 2 vols. Cairo: Al-Hay’a al-Āmma li-Shu'ūn al-Muțābi' al-Amīriyya, 1984 .

al-Albānī, Muḥammad Nāṣir al-Dīn. Șaḥị̣ al-Adab al-mufrad li-l-Imām al-Bukhārī. Jubail, Saudi Arabia: Dār al-Ṣiddīq, 1994.

al-Bayhaqī, Abū Bakr Aḥmad b. al-Ḥusayn b. 'Alī. Al-Sunan al-kubrā. Edited by Muḥammad 'Abd al-Qādir 'Ațā'. 11 vols. Beirut: Dār al-Kutub al-'Ilmiyya, 2010.

Brown, Peter. The Cult of the Saints: Its Rise and Function in Latin Christianity. Chicago: University of Chicago Press, 1981.

al-Dhahabī, Shams al-Dīn Muhammad b. 'Uthmān. Siyar ålam al-nubalā'. Edited by Shu'ayb al-Arna'ūṭ and Ḥusayn al-Asad. 28 vols. Beirut: Mu’assasat al-Risāla, 2001.

al-Dhahabī, Shams al-Dīn Muḥammad b. 'Uthmān. Tārīkh al-Islām wa-wafayāt al-mashāhìr wa-l-a'lām. Edited by 'Umar 'Abd al-Salām Tadmurī. 52 vols. Beirut: Dār alKitāb al-'Arabī, 2001.

Dols, Michael W. "The Theory of Magic in Healing." In Magic and Divination in Early Islam, edited by Emilie Savage-Smith, 87-101. Aldershot: Ashgate Variorum, 2004.

Doumato, Eleanor Abdella. Getting God's Ear: Women, Islam, and Healing in Saudi Arabia and the Gulf. New York: Columbia University Press, 2000.

Frankfurter, David. "The Social Context of Women's Erotic Magic in Antiquity." In Daughters of Hecate: Women and Magic in the Ancient World, edited by Kimberly Stratton and Dayna Kalleres, 319-339. Oxford and New York: Oxford University Press, 2014.

Frolov, Dmitri V. "The Spread of Literacy in Mecca and Medina at the Time of Muhammad." In The Humanities in Russia: Soros Laureates. The 1994 All-Russia Competition of Research Projects in Humanities, 133-139. Moscow: [International Science Foundation], 1997.

Geissinger, Aisha. Gender and Muslim Constructions of Exegetical Authority: A Rereading of the Classical Genre of Qur'ān Commentary. Leiden: Brill, 2015.

Geissinger, Aisha. “No, a Woman Did Not 'Edit The Qur'ān': Towards a Methodologically Coherent Approach to a Tradition Portraying a Woman and Written Quranic Materials." Journal of the American Academy of Religion, 85, no. 2 (June 2017): 416-445.

Graham, William. “Traditionalism in Islam: An Essay in Interpretation." In Islamic and Comparative Religious Studies: Selected Writings, edited by William Graham, 13-32. Farnham, Surrey: Ashgate, 2010. 
al-Ḥākim al-Naysābūrī, Abū 'Abdallāh Muḥammad b. 'Abdallāh. Al-Mustadrak 'alā lȘaḥhạyn. Edited by Ḥamdī al-Dimirdāsh Muḥammad. 10 vols. Mecca and Riyadh: Maktaba Nizār Mușțafā al-Bāz, 2000.

Haider, Najam Iftikhar. "The Geography of the isnād: Possibilities for the Reconstruction of Local Ritual Practice in the 2nd/8th Century." Der Islam 90, no. 2 (2013): 3o6-346.

Hasson, Isaac. "Contributions à l'étude des Aws et des Huarağ." Arabica 36 (1989): 135.

Ibn al-Athīr, 'Izz al-Dīn Abū l-Ḥasan 'Alī b. Muḥammad al-Jazarī. Usd al-ghāba fìma'rifat al-ṣaḥāba. Edited by 'Alī Muḥammad Mu'awwiḍ et al. 8 vols. Beirut: Dār al-Kutub al-'Ilmiyya, 2003.

Ibn al-Athīr al-Jazarī, Majd al-Dīn Abū l-Sacādāt al-Mubārak b. Muhammad. Al-Nihāya fì gharīb al-ḥadīth wa-l-athar. Edited by Ṭāhir Aḥmad al-Zāwī and Maḥmūd al-Ṭanāḥ̄. 5 vols. Cairo: 'Iysā al-Bābī al-Halabīi, 1963 .

Ibn 'Abd al-Barr, Yūsuf b. 'Abdallāh b. Muḥammad. Al-Istīābfìma'rifat al-aṣhāàb. Edited by 'Alī Muḥammad Mu'awwiḍ and 'Ādil Aḥmad 'Abd al-Mawjūd. 4 vols. Beirut: Dār al-Kutub al-'Ilmiyya, 1995 .

Ibn Abī Shayba, Abū Bakr 'Abdallāh b. Muḥammad b. Ibrāhīm. Al-Muṣannaf. Edited by Ḥamad b. 'Abdallāh al-Jum'a and Muhammad b. Ibrāhīm al-Lahịiān. 16 vols. Riyadh: Maktabat al-Rushd, 2004 .

Ibn Ḥajar al-'Asqalānī, Aḥmad b. 'Alī. Al-Iṣāba fì tamyı̄z al-ṣaḥāba. Edited by 'Ādil Aḥmad 'Abd al-Mawjūd and 'Alī Muḥammad Mu'awwiḍ. 8 vols. Beirut: Dār al-Kutub al-'Ilmiyya, 1995 .

Ibn Ḥajar al-'Asqalānī, Aḥmad b. 'Alī. Tahdhīb al-tahdhīb. Edited by Mușṭafā 'Abd alQādir 'Ațā. 12 vols. Beirut: Dār al-Kutub al-'Ilmiyya, 1994.

Ibn Hanbal, Aḥmad. Musnad al-Imām Ahmad b. Hanbal. Edited by Muhammad 'Abd al-Salām 'Abd al-Shāfì. 6 vols. Beirut: Dār al-Kutub al-'Ilmiyya, 1993.

Ibn Ḥibbān, Abū Ḥātim Muḥammad. Kitāb al-thiqāt. Edited by Ibrāhīm Shams al-Dīn and Turkī Farḥān al-Muṣtafā. 5 vols. Beirut: Dār al-Kutub al-'Ilmiyya, 1998.

Ibn Hishām b. Ayyūb al-Ḥimyarī al-Ma‘āinī, Abū Muhạmmad 'Abd al-Malik. Al-Sīra al-nabawiyya li-Ibn Hishām. Edited by Mușțafā al-Saqqā et al. Beirut: Dār al-Kutub al-'Ilmiyya, 2001.

Ibn al-Jawzī, Abū l-Faraj 'Abd al-Raḥmān b. 'Alī b. Muḥammad b. 'Alī. Gharīb al-Hadīth. Edited by 'Abd al-Mu'țī Amīn Qal'ajī. 2 vols. Beirut: Dār al-Kutub al-'Ilmiyya, 2004.

Ibn Khayyāț, Khalīfa. Kitāb al-țabaqāt. Edited by Suhayl Zakkār. 2 vols. Damascus: Ministry of Culture, 1966.

Ibn Qutayba 'Abdallāh b. Muslim. Gharīb al-Hadīth. Edited by 'Abdallāh al-Jabbūrī. 3 vols. Baghdad: al-Jumhuriyya al-'Irāqiyya Wizārat al-Awqāf Iḥyā’ al-Turāth al-Islāmī, 1977. 
Ibn Qutayba 'Abdallāh b. Muslim. Ta'wūl mukhtalif al-hadìth. Edited by Muhammad Nāfi ' al-Mușțafā. Amman: Dār al-Bashīr, and Beirut: Mu’assasat al-Risāla, 2004.

Ibn Sacd, Muḥammad. Al-Ṭabaqāt al-kubrā. Edited by Ḥamza al-Nashratī et al. 8 vols. Cairo: al-Maktaba al-Qayyima, n.d.

Ibn Shabba al-Numayrī al-Bașrī, Abū Zayd 'Umar. Tārīkh al-Madīna al-munawwara li-Ibn Shabba. Edited by Fahīm Muḥammad Shaltūt. 4 vols. Beirut: Dār al-Turāth, 1990.

Ibn Wahb b. Muslim al-Qurashī, 'Abdallāh. Al-Jāmi'fí l-ḥadìth. Edited by Mușțafā Ḥasan Muḥammad Abū l-Khayr. 2 vols. Dammam: Dār Ibn al-Jawzī, 1996.

Juynboll, Gautier H.A. Encyclopedia of Canonical Hadìth. Leiden: Brill, 2007.

al-Khațtābī, Abū Sulaymān Hạd b. Muḥammad. Ma'ālim al-sunan: sharh Sunan Abī Dāwūd. Edited by 'Abd al-Salām 'Abd al-Shāfĩ Muhammad. 4 vols. in 2. Beirut: Dār al-Kutub al-'Ilmiyya, 1996.

Kister, Meir Jacob. "Land Property and Jihād: A Discussion of Some Early Traditions." Journal of the Economic and Social History of the Orient 34, no. 3 (1991): 270-311.

Lecker, Michael. "The Bewitching of the Prophet Muhammad by the Jews: A Note $a$ propos 'Abd al-Malik b. Habīb's Mukhtasar fi l-țibb." In Jews and Arabs in Pre- and Early Islamic Arabia, edited by Michael Lecker, 561-569. Aldershot: Ashgate Variorum, 1998.

Lecker, Michael. “The Preservation of Muhammad's Letters.” In People, Tribes and Society in Arabia Around the Time of Muhammad, edited by Michael Lecker, 1-25. Aldershot: Ashgate Variorum, 2005.

Madigan, Daniel. The Qur'ân's Self-Image: Writing and Authority in Islam's Scripture. Princeton, NJ and Woodstock, Oxfordshire: Princeton University Press, 2001.

Mālik b. Anas. Muwațța' al-Imām Mālik—riwāyat Yahyā b. Yahyā al-Laythī (EnglishArabic). Translated by Muhammad Rahimuddin. Beirut: Īv li-l-Ṭabā‘a wa-Nashr, 1985.

al-Mizzī, Jamāl al-Dīn Abū l-Hajjāj Yūsuf. Tahdhīb al-kamāl fì asmā’ al-rijāl. Edited by Bashār 'Awwād Ma'rūf. 35 vols. Beirut: Mu’assasat al-Risāla, 1992.

Muqātil b. Sulaymān b. Bashīr al-Azdī. Tafsīr Muqātil b. Sulaymān. Edited by Aḥmad Farīd. 3 vols. Beirut: Dār al-Kutub al-'Ilmiyya, 2003.

Muranyi, Miklos. "The First Muslims in Mecca: A Social Basis for a New Religion?" In The Life of Muhammad, edited by Uri Rubin, 95-104. Aldershot: Ashgate Variorum, 1998.

Nadvi, Muḥammad Akram. Al-Muḥaddithāt: The Women Scholars in Islam. Oxford and London: Interface, 2007.

al-Nasā̄ì, Abū 'Abd al-Raḥmān Aḥmad b. Shu'ayb. Al-sunan al-kubrā. Edited by Abū Anas Jādallāh b. Ḥasan al-Khaddāsh. 3 vols. Riyadh: Maktabat al-Rushd, 2006.

Peters, Francis Edward. Muhammad and the Origins of Islam. Albany: State University of New York Press, 1994. 
Rubin, Uri. “Hafṣa.” In Encyclopaedia of the Qur'ān, edited by Jane Dammen McAuliffe, 2:397-398. 6 vols. Leiden: Brill, 2001.

Rubin, Uri. "Muhammad the Exorcist: Aspects of Islamic-Jewish Polemics." In Muhammad the Prophet and Arabia, edited by Uri Rubin, 94-111. Farnham: Ashgate Variorum, 2011.

al-Ṣafadī, Ṣalāḥ al-Dīn Khalīl b. Aybak. Kitāa al-Wāfí bi-l-wafayāt. Edited by Widād alQādī. Vol. 16. Wiesbaden: Franz Steiner Verlag, 1982.

al-Samhūdī, Nūr al-Dīn 'Alī b. Aḥmad al-Mișrī. Wafā̃ al-wafā bi-akhbār Dār al-Muștafā. Edited by Muḥammad Muḥȳ al-Dīn 'Abd al-Ḥamīd. 4 vols. in 2. Beirut: Dār Iḥyā' al-Turāth al-'Arabī, 1981.

Sayeed, Asma. "Muslim Women's Religious Education in Early and Classical Islam." Religion Compass 5, no. 3 (2011): 94-103.

Sayeed, Asma. Women and the Transmission of Religious Knowledge in Islam. Cambridge, UK, and New York: Cambridge University Press, 2013.

Schoeler, Gregor. "Oral Torah and Hadith: Transmission, Prohibition of Writing, Redaction." In Hadìth: Origins and Developments, edited by Harald Motzki, 67-108. Aldershot: Ashgate Variorum, 2004.

al-Ṭaḥāwī, Aḥmad b. Muḥammad b. Salāma b. 'Abd al-Malik al-Azdī. Sharh Ma'ānī alāthār. Edited by Ibrāhīm Shams al-Dīn. 4 vols. Beirut: Dār al-Kutub al-'Ilmiyya, 2006.

al-Ṭabarānī, Abū l-Qāsim Sulaymān b. Aḥmad. Mújam al-kabīr. Edited by Abū Muhamammad al-Asyūṭī. 11 vols. Beirut: Dār al-Kutub al-'Ilmiyya, 2007.

Wheeler, Brannon. Mecca and Eden: Ritual, Relics, and Territory in Islam. Chicago and London: University of Chicago Press, 2006.

Zadeh, Travis. "Magic, Marvel, and Miracle in Early Islamic Thought." In The Cambridge History of Magic and Witchcraft in the West from Antiquity to the Present, edited by David Collins, 235-267. New York: Cambridge University Press, 2015.

al-Zamakhsharī, Jārallāh Mạ̣mūd b. 'Umar. Al-Fāiq fígharīb al-ḥadīth. Edited by Muḥammad Abū l-Faḍl Ibrāhīm and 'Alī Muḥammad al-Bajāwī. 4 vols. Cairo: 'Îsā al-Bābī al-Ḥalabī, 1971. 